\title{
Comment on "Modeling of single cell cancer transformation using phase transition theory: application of the Avrami equation" by Fornalski and Dobrzyński
}

\author{
Mesut Tez ${ }^{1}$
}

Received: 9 November 2021 / Accepted: 5 December 2021 / Published online: 12 January 2022

(c) The Author(s), under exclusive licence to Springer-Verlag GmbH Germany, part of Springer Nature 2021

\section{Sir/Madam,}

With great interest I read the recent article entitled "Modeling of single cell cancer transformation using phase transition theory: application of the Avrami equation" (Fornalski and Dobrzyński 2021). I want to conguralate the authors for their work, but would like to clarify here the following points.

The most important shortcoming of the authors' model is the failure to consider the lifespan of gastric epithelial cells. As is stated by Mills and Shivdasani, "cell lineages in the stomach epithelium vary greatly in life span: from 3 to 5 days for surface-associated cells to several months for zymogenic cells, whereas the life span of mature intestinal cells ranges from 3 to 5 days for enterocytes to about 2 weeks for Paneth cells" (Mills and Shivdasani 2011). Consequently, it seems very difficult to hit epithelial cells with multiple mutations in such a short time.

Normal somatic stem cells (SSCs) are described as immature cells that have the double potential of self-renewal and differentiation. Somatic stem cells generate differentiated progenies (epithelial cells) on a regular basis, and they are maintained throughout life (Tez and Tez 2018). As emphasized by Mills and Shivdasani, "gastric stem cells are poorly understood, although they are likely to be involved in the pathogenesis of gastric cancer". Furthermore they add that because "gastric stem cells throughout the stomach respond continually to external cues and local tissue injury, they must occupy a sophisticated niche that conveys homeostatic signals as well as information about infection and inflammation" (Mills and Shivdasani 2011).

It is concluded that in modelling gastric cancer, biology of gastric epithelial stem cells and their progeny is an important feature that should be taken into account.

Declaration

Conflict of interest The author declared no conflict of interest.

\section{References}

Fornalski KW, Dobrzyński L (2021) Modeling of single cell cancer transformation using phase transition theory: application of the Avrami equation. Radiat Environ Biophys. https://doi.org/10. 1007/s00411-021-00948-0

Mills JC, Shivdasani RA (2011) Gastric epithelial stem cells. Gastroenterology 140(2):412-424. https://doi.org/10.1053/j.gastro. 2010.12.001

Tez S, Tez M (2018) Chaotic adaptation theory (CAT) for cancer: a Lamarckian view. Theor Biol Forum 111:67-77

Publisher's Note Springer Nature remains neutral with regard to jurisdictional claims in published maps and institutional affiliations.

This comment refers to the article available online at https://doi. org/10.1007/s00411-021-00948-0.

Mesut Tez

mesuttez@yahoo.com

1 Ankara Numune Training and Research Hospital, Ankara

Numune Hospital, Middle East, 06100 Ankara, Turkey 